\title{
The Correlation Among Communication Apprehension, Willingness to Communicate and Speaking Ability of the Ninth Grade Students of SMP Negeri in Banyuasin I
}

\begin{abstract}
Marlia Fitriana $^{1 *}$, Indawan Syahri ${ }^{2}$
${ }^{1}$ SMP Negeri 1 Banyuasin I

${ }^{2}$ Muhammadiyah University of Palembang

*Corresponding author. Email: marliafitriana.mf@gmail.com

ABSTRACT

The correlation between communication apprehension, willingness to communicate, and speaking ability of ninth grade students at SMP Negeri in Banyuasin I was studied in this study. The research sample for this study consisted of 63 ninth-grade students from SMP Negeri in Banyuasin I in the academic year 2020/2021. This was a quantitative study. The data was gathered through the use of a questionnaire and a test. The data were analyzed using the SPSS 25 program's Pearson Product Moment and multiple regression formula to determine the relationship between communication apprehension and willingness to communicate on speaking ability. The results revealed that (1) there was no significant correlation between communication apprehension and speaking ability, with a correlation value of .089 ; and (2) there was no significant correlation between willingness to communicate and speaking ability, with a correlation value of. 226; (3) there was a substantial correlation between communication apprehension and willingness to communicate, with a correlation value of -.318; and (4) there was no correlation between communication apprehension, willingness to communicate, and speaking ability, with a correlation value of. The number is 206. According to the findings, communication apprehension and desire to communicate are not significantly related to speaking ability.
\end{abstract}

Keywords: Communication Apprehension, Communication Desire, Speaking Ability

\section{INTRODUCTION}

In learning English, one of the language skills should be mastered is speaking skill. Speaking is the ability that required the process of communicative competence, pronunciation, intonation, grammar, and vocabulary. "In the past, speaking did not have enough attention from both the teachers and students" [1].

To enable students to communicate, we need to apply the language in real communication. Barjasteh, et al [2] stated that speaking is the first mode in which children acquire language, it is part of the daily involvement of most people with language activities, and it is the prime motor of language changing. It also provides our main data for understanding bilingualism and language contact.

Moreover, "Willingness to Communicate" (WTC) is an important factor influencing better communication. Theorists believe that some people with excellent communicative competence may be unwilling to communicate when having the chance. The second factor of "Communication Apprehension (CA)" refers to a person's level of anxiety when they anticipate having to communicate". That means persons with a high level of $\mathrm{CA}$ are more likely to avoid communication than individuals with lower levels of CA. Although English language is not the national language of Indonesian, we cannot overlook the fact that it has played a role in Indonesian education for a long time.

Although learners' disinclination to speak might be due to many reasons, their levels of CA may also play a crucial role in affecting their desire to keep quiet. Accordingly, exploring possible relationship between learners' CA and their speaking ability and WTC may enable teachers to gain a better understanding of the interaction among the variables and make better predictions about learners' communicative behavior. It may also offer new techniques and methods for motivating students to talk. In cases students suffer from high levels of anxiety, language teaching tasks and class activities should be adopted in a way that lessen or at least do not increase learners' degrees of apprehension. 
The 2013 curriculum was introduced at SMP Negeri in Banyuasin I. The study studied ninth-grade students at SMP Negeri in Banyuasin I. According to the 2013 curriculum, ninth grade students were required to be able to speak, and one of the materials was explanation text.

The difficulties of speaking English were faced by the learners. Based on the writer experience as a teacher of English, the learners were commonly confused to speak English when the teacher asks them to answer the question in English. The students should recognize the generic structure and language features of explanation text. Meanwhile, students must distinguish and comprehend in context based on social function, text structure, and oral and written language features related to the real problem. The researcher focuses solely on the spoken part of speaking in this study. According to the data taken from the SMP Negeri in Banyuasin I the students' speaking practice scores were under school standard value (72). The problem happened because of they had communication apprehension as a result, they were unable to perform well in English speaking. According to preliminary research by a researcher at SMPN in Banyuasin I. Most of the students have problem in communication apprehension and their willingness to communicate. When the researcher interviewed some of the students, they stated that they cannot speak English, that they are afraid to speak because they do not know certain vocabulary, and that they are afraid if they make mistake in pronunciation or mispronunciation. On the other hand, When the researcher observes the students in class directly, the researcher discovers that the teacher asks students to come to the front of the class, the teacher commands the students to explain their daily activities, and as a result, the students will speak and explain their daily activities. It means that the researcher believes the students can speak correctly and with good pronunciation, but they are also concerned about their ability to communicate with one another.

Communication apprehension (CA) is considered as "the level of anxiety of an individual when they anticipate having to communicate" [3]. That means persons with a high level of $\mathrm{CA}$ will tend to avoid communication more than persons who have lower levels of CA. They do this in order to avoid encountering negative experiences or anxiety-producing situations that they expect in communication encounters. However, it does not mean that the person with high levels of CA will never communicate in any situation [3]. On the contrary, the person decides to do so less frequently than persons with lower levels of CA.

Since its original formulation by McCroskey [3], the concept of communication apprehension has undergone a revision by McCroskey [3] divide CA into two types: trait-like and contextbased or stage.) defines trait-like $\mathrm{CA}$ as "a relatively enduring, personality-type orientation toward a given mode of communication across a wide variety of contexts". That is, it refers to enduring personal traits such as shyness. Meanwhile, context-based or state CA is apprehension in a given communication situation; for example, discussion in a group of strangers, or communication with an important person while interviewing for a new job. Regardless of the operationalization of the construct, researchers affirm that individuals who experience fear or anxiety about speaking have a tendency to avoid communication. Moreover, an individual's willingness to communicate is directly affected by CA.

According to McKool [4], Reading interest is characterized as reading done by students when they are not in the school compound. Reading interest is defined as whether or not students want to read in their spare time, at home, or at the library. Furthermore, reading interest is characterized by the number of books read in a month, the number of times students read per week, and the preferred genres and types of English reading interest.

According to Thomas [6], Reading interest refers to how enthusiastic a person is about reading written material. It may also refer to a person's perception of how stimulating or satisfying reading material can be. Reading interest, according to Thomas [6], revolves around an individual's attitude toward the process of reading, and towards different reading materials. Reading interest can be defined as student's attention, encourage effort, and support learning. Moreover, it is to be expected that students' approaches to different subjects will differ, just as their backgrounds and basic skills will differ.

Speaking has been considered as the most conspicuous kind of language ability and proficiency enabling learners to meet their basic needs. Speaking is a challenging process in which, based on the cultural and social context, speakers should decide why, how, and when to communicate [7]. Speaking has been viewed differently in the last few decades. Up to the end of the 1960s and within the environmentalist approach, speaking was mainly the result of stimulus-responsereinforcement cycles and therefore included repetition, imitation and memorization of the input in isolation. Later, with the emergence of the interactions approach and cognitive psychology, more emphasis was put on the dynamic and interactive aspects of speaking. Functions produced by spoken language, in addition to social and contextual factors, were considered to be important. Now, due to the influence of cognitive psychology, functional, and pragmatic views of language, speaking is seen as an interactive, social, and contextualized communicative event

Speaking ability can be tested either directly or indirectly. In indirect tests, trained examiners evaluate examinees' ability through using a number of elicitation techniques such as asking examinees to describe a picture, make transformation, follow commands, retell a story, explain objects, and so forth. In direct tests, reallife situations are simulated. The best example and the 
most valid type of direct tests is interview which involves at least two interviewers and interviewee. Interviews usually start with simple questions and move to more difficult ones [8]. In addition, individual's oral proficiency can be evaluated by self, peer, and teacher assessments. Providing students with opportunities wherein they can evaluate their own performance is of paramount importance as it enables them to construct and reconstruct their knowledge. Self-assessment helps language learners to bridge the gap between what they already know and their new experience and therefore enhances their understanding [9]. The researchers claimed that a positive correlation exists between self, peer, and teacher assessments. Consequently, self and peer assessments can be viewed as reliable sources of evaluating one's speaking ability.

Based on the preceding examples, the author wishes to investigate the relationship between communication apprehension, desire to communicate, and speaking ability. The researcher is interested in conducting a study named, "The Correlation among Communication Apprehension, Willingness to Communicate and Speaking Ability of the Ninth Grade Students of SMP Negeri in Banyuasin I".

\section{METHODS}

In this study, a correlation method will be used by the researcher to investigate the correlation among variables, both dependent and independent. Independent variable is a variable which affects another variable's value. Meanwhile a dependent variable is a variable that can change the value when the value of another variable changes [9], The research has two independent variables. They were communication apprehension as $\mathrm{X} 1$ and willingness to communicate as X2. The dependent variable was speaking ability as Y. Fraenkel [10], mention "correlation research attempts to investigate possible relationship among variables without trying to influence those variables." It entailed gathering data to ascertain the extent to which a relationship exists between two or more variables.
The study was carried out on ninth-grade students at SMP Negeri in Banyuasin I. The data for this study was gathered in two ways. To begin, two separate questionnaires were used to collect data on the predictor variables: the students' communication apprehension questionnaire and the willingness to communicate questionnaire. By using a speaking test, the ninth grade pupils of SMP Negeri in Banyuasin I were assessed on the criterion variable of speaking ability.

\section{RESULTS AND DISCUSSION}

In this part of the data were described on the basis of their frequency, mean, standard deviation, variance, range, minimum, maximum score. All of the instruments were given to the students that were in the ninth grade students of SMPN 1, SMPN 2 and SMPN 3 in Banyuasin I.

\section{1) The Correlation between Communication Apprehension and Speaking Ability}

The correlation analysis between communication apprehension and speaking ability revealed no significant correlation based on Pearson Product Moment correlation. The significance level was 0.487 , which was greater than 0.05 . This means that H01 was approved, while Ha1 was rejected. Further, there was no significant correlation between the communication apprehension and speaking ability students in the ninth grade at SMP Negeri in Banyuasin I. The correlation coefficient (r) was -.089, so the level of correlation analysis was in weak category or inversely correlated. It means the success in speaking skill is does not closely to communication apprehension. In this case it has been concluded that communication apprehension is not leading factor directly affects their speaking skill ability.

The result of the correlation analysis can be seen in the table below.

\section{Correlations}

\begin{tabular}{|ll|r|r|}
\hline & & $\begin{array}{c}\text { Communication_ } \\
\text { Apprehension }\end{array}$ & $\begin{array}{r}\text { Speaking_Sco } \\
\text { re }\end{array}$ \\
\hline $\begin{array}{l}\text { Communication_Appreh } \\
\text { ension }\end{array}$ & Pearson Correlation & 1 & -.089 \\
\cline { 2 - 4 } & Sig. (2-tailed) & & .487 \\
\cline { 2 - 4 } & $\mathrm{N}$ & 63 & 63 \\
\hline Speaking_Score & Pearson Correlation & -.089 & 1 \\
\cline { 2 - 4 } & Sig. (2-tailed) & .487 & \\
\cline { 2 - 4 } & $\mathrm{N}$ & 63 & 63 \\
\hline
\end{tabular}




\section{2) The Correlation between Willingness to} Communicate and Speaking Ability

Based on Pearson Product Moment correlation, the result of correlation analysis between willingness to communicate and speaking ability showed no significance correlation. The significance level was 0.075 , which was greater than 0.05 . That is, H02 was accepted while $\mathrm{Ha} 2$ was rejected. Furthermore, there was no significant relationship between the willingness to communicate and speaking ability of SMP Negeri ninth grade students in Banyuasin I. The correlation coefficient (r) was.226, indicating that the level of correlation analysis was .226. So, the level of correlation was in weak category or inversely correlated.

The result of the correlation analysis can be seen in the table below.

Correlations

\begin{tabular}{|c|c|c|c|}
\hline & & $\begin{array}{l}\text { Willingness_to_C } \\
\text { ommunicate }\end{array}$ & $\begin{array}{c}\text { Speaking_Sco } \\
\text { re }\end{array}$ \\
\hline \multirow{3}{*}{$\begin{array}{l}\text { Willingness_to_Commu } \\
\text { nicate }\end{array}$} & Pearson Correlation & 1 & .226 \\
\hline & Sig. (2-tailed) & & .075 \\
\hline & $\mathrm{N}$ & 63 & 63 \\
\hline \multirow[t]{3}{*}{ Speaking_Score } & Pearson Correlation & .226 & 1 \\
\hline & Sig. (2-tailed) & .075 & \\
\hline & $\mathrm{N}$ & 63 & 63 \\
\hline
\end{tabular}

3) The Relationship Between Communication Fear and Willingness to Communicate

The outcome of a correlation analysis between communication apprehension and desire to communicate was based on Pearson Product Moment correlation showed that significance score was .011. The significance level of.011 was less than 0.05. That is, H03 was rejected, while Ha3 was accepted. Furthermore, there was a significant correlation between communication apprehension and willingness to communicate among ninth-grade SMP Negeri students in Banyuasin I. The correlation coefficient (r) was -.318, indicating that the level of correlation analysis was poor or inversely correlated. It means the success in willingness to communicate does not closely to communication apprehension. In this case it has been concluded that communication apprehension is not leading factor that directly affects their willingness to communicate.

It could be concluded that communication

Table 4.

\begin{tabular}{|c|c|c|c|c|c|}
\hline Model & $\begin{array}{l}\text { Sum of } \\
\text { Squares }\end{array}$ & df & $\begin{array}{c}\text { Mean } \\
\text { Square }\end{array}$ & $\mathrm{F}$ & Sig. \\
\hline 1 Regression & 159.222 & 2 & 79.611 & 1.622 & $.206^{\mathrm{b}}$ \\
\hline Residual & 2944.778 & 60 & 49.080 & & \\
\hline Total & 3104.000 & 62 & & & \\
\hline
\end{tabular}

a. Dependent Variable: Speaking Score

b. Predictors: (Constant), Willingness to Communicate, Communication Apprehension

4) The Correlations among Communication Apprehension $\left(\mathrm{X}_{1}\right)$, Willingness to Communicate $\left(\mathrm{X}_{2}\right)$ and Speaking Ability (Y).

There is no significant correlation between communication apprehension, willingness to communicate, and speaking ability. The significance level was 0.206 , which was greater than 0.05 . That is, H04 was accepted while Ha4 was rejected. As a result, there was no meaningful relationship between communication apprehension, willingness to communicate and speaking ability of the the 9th grade students of SMP Negeri in Banyuasin I. The result of the correlation analysis can be seen in the table below.
Concerning the first research issue, the hypothesis proved that there was no significant correlation between communication apprehension and speaking ability. The result of $\mathrm{rx} 1 \mathrm{y}=-0.089$. Pearson Product Moment shows that the result of correlation analysis indicated that the significance score 0.487 was higher than $\alpha 0.05$. That is, H01 was accepted while Ha1 was rejected. It means that there was no significant correlation between communication apprehension and SMP Negeri's ninthgrade students in Banyuasin I's speaking skills. In brief, the increase of students' communication apprehension is followed by the decrease of speaking ability. When the students' have high communication apprehension, it 
may open the possibility for the students do not take their seriousness in learning English.

In the process of foreign language learning, communication apprehension plays a significant role. In addition, speaking is believed to be at the center of anxiety provoking tasks (Horwitz, Horwitz, \& Cope, 1986). Finding any relationship, therefore, is of great importance. In the study, the researcher found that, except for the level of communication apprehension within a meeting context, there exists no considerable correlation between communication apprehension, subcategories of communication apprehension, and speaking ability.

The second result from the hypothesis proved there was no significant correlation between willingness to communicate and speaking ability. The result of $\Gamma \mathrm{x} 2 \mathrm{y}=$ 0.226 included low correlation interpretation. The result of correlation analysis shows that the significance score 0.075 was higher than $\alpha 0.05$; H02 was accepted, while Ha2 was rejected. Further, there was no significant correlation between the willingness to communicate and speaking ability of the 9th grade students of SMP Negeri in Banyuasin I.

The second result from the hypothesis proved there was no significant correlation between willingness to communicate and speaking ability. The result of $\mathrm{rx} 2 \mathrm{y}=$ 0.226 included low correlation interpretation. The result of correlation analysis shows that the significance score 0.075 was higher than $\alpha 0.05$; H02 was accepted, while $\mathrm{Ha} 2$ was rejected. Further, there was no significant correlation between the willingness to communicate and speaking ability of the the 9th grade students of SMP Negeri in Banyuasin I.

Whether students initiate a conversation with a specific person at a particular point in time and in a certain context is probably a spur-of-the-moment decision that individuals make based on all factors available in a communicative encounter. In fact, probably the decision to initiate a conversation is much more influenced by students' situational willingness to communicate rather than their general willingness to communicate. Accordingly, it can be said that students' general tendency toward or away from a communicative encounter does not influence their oral proficiency. However, it might be their moment-to-moment decision to initiate an interaction that leads to the development of their language production. In other words, what might be more important in academic and formal classroom settings is students' situational willingness to communicate which, as Kang (2005) asserted, is simultaneously influenced by factors such as sense of security, excitement, responsibility, etc. Nonetheless, students' general Unwillingness to communicate does affect their situational willingness to communicate.
It should also be noted that although willingness to communicate and speaking ability were not directly related to each other, higher levels of willingness to communicate could eventually lead individuals to have better oral proficiency. Within an academic environment, willingness to communicate influences the frequency of L2 [11]. The more students engage in class discussions, the more chance they have to receive teachers' feedback. As stated, such a factor gives the impression that the frequency of the L2 use is possibly the source of higher proficiency.

Third, the result from the hypothesis proved there was significant correlation or between communication apprehension and willingness to communicate. The result of $\Gamma \times 3 y=-0.318$ included low correlation interpretation. The result of correlation analysis shows that significance score was 0.011 was lower than $\alpha 0.05$; H03 was accepted, while Ha3 was rejected.

According to the study's findings, it was found that there was negative and significant correlation between the students' communication apprehension and willingness to communicate of the the 9th grade students of SMP Negeri in Banyuasin I. If we interpret it based on the table of the Strength of Correlation Coefficient, it can be inferred that there is very weak correlation between the students' communication apprehension and willingness to communicate of the the 9th grade students of SMP Negeri in Banyuasin I.

Horwitz, et al [12] believed that individuals' selfperceived oral communication competence and communication apprehension correlate negatively. As Vevea [13] stated, students who are more willing to communicate have lower levels of communication apprehension. Coming back to the findings of the current study a negative correlation coefficient is observed between students' communication apprehension and willingness to communicate. This suggests that as students were more willing to communicate, they had lower levels of communication apprehension. On the one hand, students' willingness to communicate provokes them to approach a communicative encounter and on the other hand, their communication apprehension provokes them to avoid it. Such being the case, it is possible that communication apprehension is a predictor of willingness to communicate in language classes because the majority of highly apprehensive students were less motivated to begin a conversation.

The final hypothesis was tested using correlation analysis and regression between communication apprehension and willingness to communicate, as well as speaking ability, with $\mathrm{X}_{1} \mathrm{X}_{2} \mathrm{X}_{3} \mathrm{Y}=0.206$. The significance level was 0.206 , which was greater than 0.05. It means there was no significant correlation among variables $\mathrm{X}$ on variable $\mathrm{Y}$. It demonstrated that if students' communication apprehension and willingness 
to communicate were low, so would their speaking ability.

Speaking in meetings, according to Kang [13], is associated with the anxious feeling that people have when they are in actual or expected communication with others in a very small group, such as a class. Meetings are generally considered as formal situations and as Oladipo, et al [14] suggested in these situations individuals might suffer from high levels of communication apprehension. Their lack of familiarity with the situation may also be influential. Unfamiliarity probably makes learners less confident and more insecure in a way that they prefer to withdraw a communicative encounter [15]. Consequently, it is highly suggested that such factors should be avoided to the extent possible in academic contexts.

\section{CONCLUSION}

Based on the discussion of the study results, the following conclusions are reached: 1) there is no significant correlation between communication apprehension and speaking ability among Banyuasin I ninth grade students at SMP Negeri; 2) there is no significant relationship between willingness to communicate and speaking ability among Banyuasin I ninth grade students at SMP Negeri; 3) there is a substantial relationship between communication apprehension and willingness to communicate among ninth-grade SMP Negeri students in Banyuasin I, and 4) there is no significant relationship between communication apprehension, willingness to communicate, and concurrent speaking ability of ninth grade students at SMP Negeri I in Banyuasin.

\section{ACKNOWLEDGMENTS}

Our deepest gratitude goes to Teachers in SMP Negeri 1 Banyuasin I, Chancellor of Palembang PGRI University, Director of the Postgraduate Program of PGRI Palembang University and the Education Management Study Program of PGRI Palembang University, who have supported us in doing this extraordinary thing. This project is funded independently. We also want to thank our Education Management friends who helped us a lot in a short time frame to complete this project.

\section{REFERENCES}

[1] Fang-peng. G., and Dong, Y. (2010). A Study on College Students' Anxiety to Spoken English. Canadian Social Science, Vol. 6, No. 2. Retrieved from

http//cscanada.net/index.php/css/article/viewFile/1 $257 / 1331$.

[2] Barjasteh, H., Vaseghi, R., \& Neissi, S. (2012). Iranian EFL learners' willingness to communicate across different context- and receiver-types.
International Journal of English Linguistics, 2(1), 47-54.

[3] McCroskey, J.C. (1970). Human communication. A Publication of the Pacific and Asian Communication Association, 12, (2), 157-171.

[4] Amogne, D., \& Yigzaw, A. (2013). Oral communication apprehension, competence and performance among maritime engineering trainees. Journal of Media and Communication Studies, 5(1), 5-11.

[5] Baghaei, P. D., \& Dourakhshan, A. (2012). The relationship between willingness to communicate and success in learning English as a foreign language. $M J A L, 4(2)$, 53-67.

[6] Thomas, A. (2009). Multiple Intelligence in the Classroom (3rd ed.). New York, NY: Pearson Education Inc.

[7] Martínez-Flor, A., Usó-Juan, E., \& Soler, E. A. (2006). Towards acquiring communicative competence through speaking. In: E. Usó-Juan, \& A.

[8] Farhady, H. Ja'farpur, A. J., \& Birjandi, P. (1994). Testing language skills from theory to practice. Tehran: SAMT.

[9] Shukla, S. (2018). Variables, hypotheses and stages of research (p. 2). Gujarat, India: Gujarat University.

[10] Fraenkel, J.R., Wallen, N.E., and hyun, H.H. (2012). How to Design and Evaluate Research in Education. New York: McGraw-Hill Companies, Inc.

[11] Hashimoto, Y. (2002). Motivation and willingness to communicate as predictors of reported L2 use: The Japanese ESL context. Second Language Studies, 20(2), 29-70.

[12] Horwitz, E. K., Horwitz, M. B., \& Cope, J. (1986). Foreign Language classroom anxiety. The Modern Language Journal, 70(2), 125-132.

[13] Kang, S. (2005). Dynamic emergence of situational willingness to communicate in a second language. System, 33(2), 277-292.

[14] Oladipo, S. E., Agbajeola, R. O., \& Adenaike, F. A. (2012). Assessing communication apprehension among in-service teachers in a university of education. Research on Humanities and Social Sciences, 2(7), 27-31.

[15] Soureshjani, K. H. (2012). The interplay of proficiency level and communication apprehension among EFL learners with a look at their preferences of communicative tasks. International Journal of Instructional Technology and Distance Learning, 9(4), 49-57. 